\title{
Bruce Springsteen and the Story of Us Hope Edelman
}

THE FIRST TIME I HEARD a Bruce Springsteen song performed live was in 1979, when I was in the tenth grade and Larry Weinberger and A.J. DeStefano stood in our high school parking lot shouting all the words to "Thunder Road" from start to finish, zipping right through that tune at fast-forward speed. Eyes squeezed shut into brief black hyphens, shoulders pumping to an imaginary drumbeat, they sang to an audience of ten or twelve sophomores sprawled against the hoods of their parents' old cars, their red and green and blue looseleaf binders strewn right side up and upside down like blackjack hands along the pavement at their feet.

This was October, the second month of the school year, and the time between 3:40 P.M. and dinner was still a flat landscape of vast and open hours. A single cigarette slowly made its way around the circle, passed between the tight Vs of fingers and held just long enough for each of us to blow a smoke ring for effect. Across the parking lot, students called to each other by last name ("Yo, Speee-VAK!"), car doors slammed, engines revved like short-lived lawn mowers. Larry and A.J. finished their song and started on "Jungleland," pausing after "The Magic Rat drove his sleek machine over the Jersey state line" just long enough to allow:

"Into Rockland County!"

"The Ramapough Inn!"

"Yo mama's backyard!"

"Hey! Your sister's bedroom, asshole."

We all knew the words to Springsteen's songs, and we knew, firsthand, most of the places they described. Some of them practically were in our parents' backyards. We were living in New York, just over the New Jersey border in the tiny towns that dot the bottom of the state map like scattered flecks of black pepper, a county filled with minor suburbs most frequently described by their relative position to somewhere else: thirty-three miles northwest of Manhattan, less than a one-hour drive from two international airports, and a half tank of gas north of the Jersey shore.

Springsteen Country, our bumper stickers read, though most of us took thick black magic markers and crossed out the second R. Springsteen County 
was far more accurate for a place where high school principals considered "Jungleland" appropriate music to play over the homeroom P.A. system; where parents routinely dropped off their children in front of Ticketron offices fortified with sleeping bags and pastrami sandwiches, returning the next morning to carpool them to school; and where sixteen-year-olds held parties in empty parking lots on heavy, humid, late-summer nights, where they sat on the hoods of cars and swirled beer around in the can, listening to Springsteen sing about a barefoot girl on the hood of a Dodge drinking warm beer in the soft summer rain. It was enough to make you wonder where the scene ended and the song began, or if there really were a difference, at all.

Those were our years of music, back when we still could find simple, one-step answers to life's most complex problems in the lyrics of the songs we sang, back when a deejay's mellifluous voice could still smooth out all the rough edges of a day. In those years, the late ' 70 s and early ' 80 s, we plucked our role models from the FM dial-Bruce Springsteen, John Cougar, Joan Jett, a cast list of sensitive survivors, underdogs with good intentions, minor idols who neatly met our critical adolescent need to constantly feel wronged without ever actually doing anything wrong, and we aligned our frustrations with the lyrical mini-dramas scripted for us in advance. Our mythology was created and recycled, and recycled and recycled, every day.

Though we liked to imagine ourselves as the kind of characters that peopled Springsteen's songs-he was, after all, writing about us - the fit was never quite right. We had pretty much the same anxieties, but the socioeconomics were all wrong. He sang of working-class kids stuck in deadend towns who grabbed their girlfriends by the wrists, leapt into their rebuilt ' 69 Chevys and peeled out of town in search of their futures. Our hometown was an upper-middle-class suburb where a college education was more an expectation than an exercise in free will. Most of us would grow up to become just what our parents had planned, and to do just as they had done. Doctor, lawyer, C.P.A. But in the time we had before our decisions became too intractable to erase, we were free to try on and shrug off whatever clothing best fit our erratic moods. Even the most intelligent, even the most affluent among us had visions of a utopia free of parents, P.E. teachers, and pop quizzes. Springsteen offered us his version of that place, his promises surrounding us like audio wallpaper-hogging the airwaves on 
our car radios, piped into our homerooms, pumped into every store in our local indoor shopping mall, encircling us with songs of hot desire and escape.

This was 1978, 1979, and in the magazine interviews we passed from desk to desk in social studies class Springsteen told us he would never change, would never, essentially, grow up. His was a world of perpetual adolescence, an eternal seventeen. "I couldn't bring up kids," he told Rolling Stone. "I couldn't handle it. I mean, it's too heavy, it's too much.... I just don't see why people get married. It's so strange. I guess it's a nice track, but not for me."

Back then, like us, Springsteen was still living among his history, shuffling along the Asbury Park boardwalk with his hands jammed down deep in the front pockets of his jeans but his eyes fixed on the gulls that dipped and cawed on the horizon. He held tight to the Jersey towns where he began, always swore he'd never forget the people or the place, but he also knew where he wanted to go, and this duality pervaded his songs like a restless, wanton motif. His lyrics told us precisely what we wanted to hear: that when the pressures of adulthood started squeezing us too tight we could just peel out, leaving skid marks as our contemptuous farewell, and his music could, in the course of only three minutes, transform a solitary harmonica wail into a full band battle cry, the cymbals crashing one, two, three like a bedroom door slamming shut over and over again.

But I'm talking early Springsteen here, vintage Springsteen, those pre1980 songs that put you in a fast car and took you on a one-way ride through images that came quick and fast as lightning, no time to bother with a chorus you could return to and repeat when you lost your place in the stream of consciousness lyrics that rambled on and on like Kerouac sentences in search of a period. The songs that gave you hope there was a simpler, gentler world out there somewhere, and that the happiness missing from your own backyard could be found in the next town. This was back before he cut his hair short and sprouted biceps, back when the guitar chords still came down angry and loud and an unshaven, scrawny Springsteen rooted himself behind the mike with a guitar pressed tight against his groin, his shoulders and neck twitching spastically in time with the beat. Back when you could still tell a lot about a man by the lyrics that he sang, and when you thought Bruce Springsteen knew a lot about you, as you lay alone on your twin bed with the door slammed shut and the hi-fi turned up to 9 , 
listening to him play the piano introduction to "Jungleland" the way he did it every time, with his left hand firmly anchored in the bass chords as his right hand skittered manically up and down the soprano notes, flailing like a frantic fish, fluttering like wings.

When I met Jimmy T., I was seventeen and still a virgin, and three weeks later I was neither anymore. We did it for the first time on a Saturday afternoon in his lumpy double bed underneath guitars that hung suspended from a ceiling rack like electric pots and pans. He had a chair jammed under the doorknob and WPLJ turned up loud enough to mask our noise, and sometimes when the radio hit a bass note, a guitar string buzzed above my head. Two hours of songs must have played that afternoon, but the only one I remember is Springsteen's "Hungry Heart," because as soon as he heard the opening chords Jimmy T. started to hum and thrust in rhythm to the song. Got a wife and kids in Baltimore Jack, I went out for a ride and I never went back. Jimmy T. assured me that losing his virginity at age thirteen made him eminently qualified to relieve me of mine without unnecessary pain or pomp. He was right, on both counts, but I was disappointed nonetheless. I'd been prepared for several unsuccessful attempts, searing pain, and the kind of hysterical bleeding Sylvia Plath had described in The Bell Jar. The ease of it made me wonder, at first, if we'd done it right.

I was the last among his friends to lose it but the first among mine, and when I left his parents' house I drove straight to my friend Jody's, walked down the hall to her room, sat down carefully on her white-ruffled canopy bed, and started to cry.

"Holy shit..." she whispered, and when I nodded she threw her arms around my chest and hugged me, hard.

"Holy shit!" she shouted, bouncing her butt up and down on the bed. "Holy SHIT! TELL ME WHAT IT'S LIKE!"

What was it like? What was any of it like? Like one long manic car ride on an open stretch of road with a driver whose license had wisely been revoked. And I'm not talking just about the sex part. It was like that all the time with Jimmy $\mathrm{T}$. He could get a whole room of people singing with no more than five words of encouragement and a chord on his guitar, and when we went to the movies he'd have met everyone in our row and even collected a phone number or two by the time I came back with the popcorn and Junior Mints. The intersection of a precocious intellect with a 
cool-guy delivery had him performing monologues about hypothetical conversations between Hitler, Santayana, and Christ ("So, the Nazi dude would have said to the Jewish dude, man...") to his small group of smokingsection disciples during lunchtime, after he'd cut three classes that morning and had to beg his English teacher to give him a passing grade. His mother once told me his I.Q. was 145 , a fact I found suspicious considering he'd never learned how to spell.

Jimmy T. Just look at his name. James Anthony Spinelli was the full version, but he wouldn't answer to James or Jim and he always included the T. For Tony. When I reminded him that his middle name was Anthony, and shouldn't he then be Jimmy A.? he gave me a crooked half-smile and raised his open palms in a shrug. I told him Jimmy T. sounded like a name he got from a fourth-grade teacher with too many Jimmys in one class, and he laughed and created a list of last names he might have had, had this been true: Tortoni, Turino, Testarossa. Jimmy Traviata at your service, he'd say, opening the car door for me with a flourish of the wrist and a bow. Jimmy Tortellini here to escort you to Spanish class. My mother would have called him a man with presence, like Frank Sinatra or Tom Jones. The kind of man, she said, who can take your heart away.

Jimmy T., I'm certain, would have considered this a compliment. In fact, if it'd been on paper, he probably would have tried to autograph it. At seventeen he already envisioned himself as a celebrity of sorts, with an existence worth chronicling as it unfolded. Write the story of us, he used to say, assigning the task to me, because I was the one who would conform to the rules of grammar and could spell. But he was the storyteller among us, the one with the elaborate narratives of drag races and secret meetings with record executives, and of playing his guitar in smoky SRO bars where audiences lifted their brown beer bottles and shouted for more. Stories I would have immediately thought unbelievable had they not been told with such authority, such grace. Write the story of us, he would say, the "us" squeezing implied chapters between its two characters, but when I tried I could never get past our first, unremarkable conversation at a party in a cheap motel room at the New Jersey shore. The people who appeared on my pages were insipid and one-dimensional, nothing at all like the characters we aspired to be, and my efforts turned into crumpled wads of paper I tossed against his bedroom walls. 
I spent most of my after-school hours between those walls, preferring to close a bedroom door against the silence of Jimmy T.'s house than against the disorder of my own. This was 1982. The summer before, my mother had died of cancer, quickly and unexpectedly, leaving my father to care for three children, ages seventeen, fourteen, and nine. When we returned from the hospital he looked at us and blinked quizzically, as if to ask, Have we met? and I realized for the first time how fragile a balance life must be, if it can be tipped so swiftly, so dramatically and irrevocably by the force of a single event. Only after my mother was gone did I understand she'd been the only adhesive that had held us all together, and as the empty Scotch bottles multiplied on the kitchen counter my father began to spout increasingly weird and existential rhetoric about how the individual is more important than the unit, and how we all must learn to fend for ourselves. I'm doing just fine, thank you, he hollered when he found me one evening pouring honeycolored streams of alcohol down the avocado kitchen sink. And I don't need you or anyone else to tell me how to live my life. Then don't you tell me how to live mine, I screamed back in a defensive panic, and he yelled Fine! and I yelled Fine! and everything, perhaps, would have been just fine, except that very soon I began to feel like a tiny, solitary satellite orbiting way out there, connected to nothing and no one, even after my father apologized and sent me on vacation to Florida to show how much he really meant it. I just smiled and kept saying everything was fine.

That was the fall I became obsessed with J.D. Salinger, read each of his books four times and began to quote esoteric Zen koans at wholly inappropriate cafeteria moments, and for an entire week that winter I ate nothing but ice cream and wore nothing but black. When teachers kept me after class to ask how I was doing, I said, with great conviction, I am doing just fine. But when you're out there spinning solo, it's only a matter of time before you get close enough to someone else's gravitational pull.That spring, Jimmy $\mathrm{T}$. came trucking across the dirt-brown motel room carpet, black curls flapping and motorcycle boots clomping with each step, to sit next to me on the orange bedspread. He was a senior with a fast car, a reputation, and a Fender Stratocaster electric guitar. I didn't dare say anything as plebian as hello.

Our first, unremarkable conversation: He said So, and I said So, and he said Hope? and I said Jimmy T., and he said Yeah, and I said Yeah, and he said 
Cigarette? and pulled a pack from his back pocket, and I said Match? and pulled a book from mine, and he said Thanks, and I said Thanks, and he said Shit! I know you can use words with more than one syllable because I see you walking out of that AP English class every day.

It didn't take me much to fall in love at seventeen-the graceful arc of a smooth-shaven jaw, the smell of freshly washed hair, the sound of a telephone ringing at precisely the moment of the promised call. After Jimmy $\mathrm{T}$. and I returned from the beach that Sunday, we intertwined our fingers and we held on tight. Two weeks later, we were officially in love.

We spent every afternoon together, in his bedroom at the top of the stairs. Jimmy T. played songs he said he'd written for me, on the beat-up acoustic guitar he'd bought with birthday money when he was twelve. He and his friend George had written a song on it they'd sold to a record label the previous year, a tune Jimmy T. played for me over and over again as I sat cross-legged on his bed. We kept the curtains drawn. His room was dark and womblike, like a tight hug, and far removed from the bright yellowand-green pep of my own. The verve of my bedroom had become a hypocrisy in my father's house, where dust had settled on the living room tables and a television droned constantly in the background to give the illusion of discourse. The downstairs bedroom that once had been my sanctuary from mother-daughter strife had transformed into something foreign and surreal. I'd grown much older than seventeen that year, but every time I walked into my room the geometric mobiles and kitten posters along its perimeter told me I'd once been that age, and not so very long ago.

Jimmy T.'s room, on the other hand, was testimony to postmodern teenage chaos: stereo components and recording equipment stacked schizophrenically against the walls; cassette and eight-track tapes scattered like loose change across the floor; Muppet dolls hanging in nooses from the ceiling; six-year-old posters of Bruce Springsteen taped to the sliding closet doors; and pages and pages of handwritten sheet music layered like onion skin on top of his dresser, desk, and bed. Jimmy T. was working on a project, he said, a big one that the record company was anxiously waiting to see. It would take him another two years, he said, maybe three. He couldn't reveal its content yet, but he said it had the potential to change the world. Three years, maybe four. He didn't think the world could wait much longer than that. 
He'd chosen music as his medium, he said, because it was the most influential, the most powerful forum for widespread philosophical reform, our last-gasp hope to save our youth from an impending spiritual decline, and he was certain he'd be the one who'd one day use his guitar to make the difference that mattered. But he'd have to get moving soon, he said, seeing as how he was already certain he wouldn't live past forty.

"I mean, shit," he said. "Look at Springsteen. He's already pushing thirtyfive. All right, the man's a genius, he's changed my life, but how many years does he really have left? Okay, I'm seventeen now, right? So say I take off at twenty, maybe twenty-one. Can you imagine how much I'd get done if I got started then?"

He told me this the night we met, as we walked along the beach before dawn. It was no surprise that our conversation quickly skidded into music, one of the few common denominators that fused the three distinct groupsItalians, Blacks, and Jews-that comprised our high school student body. In English class that year we all read Shakespeare and Keats, but our real poets were the ones whose song lyrics we carefully copied onto our spiral notebook covers. When our teacher asked three students to bring in their favorite poems for the class to interpret the next day, Elisa Colavito showed up with the lyrics to "Born to Run." It was worth every five-paragraph essay we had to write that year to see Mrs. Bluestein squint at the blackboard, trying to scan and analyze Just wrap your legs round these velvet rims, and strap your hands 'cross my engines.

My yearbook is filled with hand-scribbled verses like these, all the Jackson Browne and James Taylor and Bruce Springsteen aphorisms we reached for in moments of passion or distress. I don't know how to tell you all just how crazy this life feels. Close your eyes and think of me, and soon I will be there. Baby, we were born to run. They were the greatest hits of pre-packaged sentiment, providing me with words that sounded like what I thought I was supposed to feel. I had no blueprint for emotion, no adult I trusted to tell me what I should do with my mother's winter coats, or how to feel when I heard my siblings crying alone in their rooms, or what to say to a father who drank himself to sleep each night. In the absence of any real guidance or experience, Jackson Browne's advice to hold on and hold out was as good as any I could divine on my own.

Discussing music our first night together gave Jimmy T. a convenient chance to introduce his favorite topic-Bruce Springsteen-and engage in 
open idolatry, which he did at every available moment. By our senior year, Jimmy $T$. had recreated himself almost entirely in the musician's late '70s image, adopting the appearance (long, dark hair, faded jeans, half smile), the voice (a gravelly just-got-outa-bed-and-smoked-a-packa-Marlboro grumble), the transportation ('69 Chevy with a 396, and a motorcycle, no license), and the look (chin down, eyes up, head tilted slightly to one side) we saw on album covers and in music magazine photo spreads. Jimmy $\mathrm{T}$. wasn't content to merely listen to the man; he actually wanted to be him. Which meant that I, in turn, got to be his Wendy-Annie-Rosie-Mary-Janey, his co-pilot in passion and impulse. It gave me a clear persona, straightforward and well-defined.The first time we walked hand-in-hand between the rows of metal lockers, I metamorphosed from the girl whose mother had died of cancer last year into the girl who was dating Jimmy T. - the girl who rode tandem and helmetless on his motorcycle, the girl who didn't care about safety or the law. I'd been waiting all year for someone to hand me a costume that fit so well.

It wasn't a bad deal. After all, the scenery changed every day and I never had to drive.

There are two kinds of men, my mother told me when I was sixteen: the ones who need you, and the ones who need you to need them. I eyed my father closely the year after she died, looking for some kind of clue about him, but his actions were too inconsistent, his silence too enigmatic, to help me decide either way. From across the kitchen I watched him, a big, awkward man with a woman's apron tied around his waist, carefully measuring ingredients into a microwaveable casserole dish as his glass of Scotch and soda sweated droplets onto the counter at his side. He insisted on cooking every night, but after dinner he retreated to his room where he fell asleep, snoring loudly, by nine. "He has to go to bed this early, so he can wake up for work at five," my sister insisted, in that horrible "Don't FUCK with me ... please?" tone we all mastered that year. But I knew that sometimes in the middle of the night she went to stand outside our father's room, listening for his breathing, and when she didn't hear it she opened the door a crack just to make sure she saw his chest rise and fall. I knew, because sometimes when I came in late at night I went to check for it, too.

Jimmy T. and I worked out a system: Lying on my bed downstairs, I waited until the last floorboard creaked above my head before I dialed his 
number. I let it ring only once, hanging up before either of his parents could get to the phone. When I heard his engine idling in the street I climbed out my sub-basement window, crawled across three feet of slippery bark chips and rough shrubs and then sprinted across the lawn to the Chevy's passenger door. I held my breath until the moment when the cool metal door handle connected with my palm, that concrete smack of arrival, exhaling with relief as I landed with a soft thud in his vinyl passenger seat.

We navigated the back roads after midnight, with a Springsteen tape in the cassette deck and a Mexican blanket folded on the back seat. Night was when we made our mark. "Welcome to my beaudoir," Jimmy T. liked to say, gesturing toward the open blanket as I unzipped my jeans. "Would Madame like a mint on her pillow, or perhaps the services of a personal valet?"

We fucked behind a grade school, right beside the jungle gym. We fucked in the backyards of kids we were certain hated us at school. We fucked in a park, in a parking lot, and on a dock along the Hudson River while three geese fought it out over half a bagel. It's a miracle we never got caught. We learned how to be quick about it. Maybe that's why.

Jimmy $\mathrm{T}$. always sang along with the tape as he drove me back to my father's house. He had a pretty good voice, on-key with a slight Jell-O quiver when he held onto the low notes and a scratch against the back wall of his throat when he reached for the high ones. It was a tight match to Springsteen's, and when he sang with the tape I had to listen hard to distinguish between the two. Jimmy $T$. drove with his left hand on top of the steering wheel and his right hand resting against the back of my neck. The damp summer breeze carried the scents of lawn clippings and moist tree bark through the open windows and into our hair. Sometimes I had to fight the urge to slide my left sneaker on top of Jimmy T.'s right one and press the accelerator to the floor. This was my fantasy: the two of us speeding deeper and deeper into the woods, with his right arm across my shoulders and my left palm resting against his thigh, like a couple in a tiny, private theater with a windshield as our screen.

I knew other girls like me in high school who saw their boyfriends as their saviors, turning to them for the nurturing and attention they couldn't get from home. We were everywhere, holding on to our textbooks with one hand and our boyfriends' belt loops with the other as we maneuvered through the halls; scratching their names into our arm skin with safety pins during study hall, making little love tattoos; sitting knee-to-knee in Planned Par- 
enthood conference rooms while a counselor named Joe waved flat-spring diaphragms and Pill packets in the air as he talked about "shared responsibility." Outside in the waiting room, another group sat clutching their bouquets of ten dollar bills, waiting to file in. There were so many of us, so many rooms of women, all waiting to be saved.

When Jimmy T. and I were juniors, the year before we met, his best friend Billy D'Angelo died. The local newspaper reported it as an accident, no other victims involved. It happened in late May, just a few weeks before Billy would have graduated. I'd known Billy from fifth-period lunch, when we sometimes stood in the same circle in the smoking section outside with our shoulders hunched together to protect our matches from the wind. It was no secret that his grades hadn't been good enough to get him into any college, or that his parents were beginning to turn up the volume about enlisting in the military. "The fucking army, man," he said, flicking his cigarette butt into the grass. "Like I'm really going to cut my hair and do pushups. Right."

Wild Billy, his friends called him, after Springsteen's song "Spirit in the Night." Crazy Janey and her mission man, were back in the alley trading hands, 'Long came Wild Billy with his friend G-man, all duded up for Saturday night. It's sort of a lonely song, about old friends and drugs and a single night's attempt to get away from it all, but Billy didn't seem to mind the name.

I didn't know Billy all that well, but up until the time he died I still believed the universe was a largely benevolent place run by a judicious management. In this cosmos of my imagination, people didn't die young. My mother was still alive, and though she'd been diagnosed with breast cancer the previous spring, it hadn't yet occurred to me that she might actually do something as radical as die. Her own optimism blanketed the family with a false security, allowing us to believe we could all go on living just as we always had, treating cancer and chemotherapy as temporary boarders on a month-to-month lease.

Before Billy died, death was more than just an abstraction to me. It was damn near incomprehensible. When it caught up with him, it caught up with me, too, and I was left struggling to understand the insidious speed and finality of it. One day Billy was cupping his hand around a lit match, trying to light a cigarette in the wind, and the next he was gone, a quenched flame. For the first few days after he died, I kept half-expecting him to sidle 
up next to me outdoors with an unlit Marlboro dangling from his mouth. I just couldn't wrap my mind around the idea that someone who'd always been there could suddenly be so... well, nowhere, as far as I could see.

The accident-which is what we were calling it then-had happened on a Saturday night, in a state park about fifteen miles north of town. Jimmy T. and Billy and their crowd of high school friends used to go up there after dark and race cars on the narrow roads that hugged the mountain curves. Billy had convinced Jimmy T., don't ask me how, to lend him his '65 Mustang for the ride. Kimmy Rinaldi, Billy's unofficial fiancée, pulled him over to the gravel shoulder and pleaded with him not to race. Afterward she said she'd just had a bad feeling about that night. Not bad like you were on an airplane and suddenly thought it might be on its way down, she told me, but bad enough to say something, you know? Billy told her not to worry, popped a quick, dry kiss against her mouth, and caught the key ring Jimmy T. tossed his way with a quick twist of his wrist.

What happened next happened quickly. Moments after the two cars squealed off, everyone jogged up the road to see beyond the first bend. Jimmy T. was the first to arrive, just in time to see the Mustang take a sharp right turn off the edge of the road and to hear the sickening crash and thump of metal against granite and bark as the steep forest rejected the car all the way down the mountain's side.

Jimmy $T$. took off running to where the other driver stood, already out of his car, pounding its roof with a bruised fist and crying without tears. Crying without tears, they said. "I don't get it, man. He was on the inside. I don't get it man. I don't get it." A couple more people ran over, and there was a bunch of noise and some crying, and a lot of spinning around without any real direction before someone decided it would probably be a good idea to call the cops. When Kimmy finally realized what had happened, she started screaming Billy's name, over and over again. It took three people to hold her back, to keep her from going over the edge after him.

The funeral was six days later, in a church around the corner from our school. A wave of students outfitted in tan poly-blend suits and white peasant skirts left after third period that day, all absences excused. After the service, Jimmy T. and some other friends paid their respects to Mrs. D'Angelo and told her how they hoped she'd have "Wild Billy" engraved somewhere on the headstone. They said they knew Billy would have wanted it that way. She was very kind and courteous and said Bill had been so lucky to have 
had friends as nice as them, but when the stone went up a few weeks later, it read William Christopher D'Angelo, Beloved Son and Brother, 1963-1981, and nothing more.

The story of Billy's death quickly became a dark legend told and retold up and down the hallways of our school, increasing in macabre and explicit detail until even those who'd been there couldn't separate the imaginary from the real. The car did a complete flip as it went over the cliff, or was it two, or three? Billy had called out "Kimmy!" as he went down, or was it "Jimmy!" or "Why me?!" Overnight, Billy became our romantic hero, the boy who'd died at the same fast speed at which he'd lived. Never mind that he'd really spent most of his days red-eyed and only marginally coherent in the smoking area outside. Never mind that his car left no skid marks. In myth you have no mortal limits. You can do anything. You can become a god.

I didn't really know Jimmy T. before the crash. His friends later told me that watching it had changed him, but they couldn't explain quite how. It made him more ... reckless, they said, gazing toward the ceiling as if adjectives grow between flourescent lights. More ... unpredictable. More ... well, just weirder, you know?

Yes, I wanted to say. Yes. It's easy to pinpoint the effects of a positive change, harder-unless they're clearly pathological一to recognize those that stem from a loss. Those are our tiny secrets, the runaway pieces of psyche we bury under thick layers of silence and defense. We say we're managing. We say we're doing fine. We say we don't need help and people believe us, because they want to believe us, even when our actions clearly say the opposite is true.

It took me almost a month after our first weekend at the beach to tell Jimmy T. about my mother, though of course he'd known the story all along. Everyone did, by then. I tried to pass it off matter-of-factly in the car one night-“My mother died last year, you know?"- but before I could even finish the sentence I'd begun to cry. It was still that close to the surface. He pulled into the nearest driveway and held me tight, my hands trapped between his chest and my face. He pulled them away and kissed my eyes, licking my tears like a cat. "Shh," he said. "Don't cry. Jimmy T. is here."

That night was the only night he ever talked with me about Billy dying. He told me his version of the crash story from beginning to end: about the good-luck butt slap he gave Billy before he got into the Mustang; the way 
Billy drove off with his left fist thrust out the open window and northwest into the air; and how for one crazy moment, when he first saw the car leave the ledge, he thought it might sprout wings and fly.

If only he hadn't given Billy the keys, Jimmy T. whispered. If only Kimmy had complained a little more. If only he'd been driving the car, Jimmy T. said, and that's when he started to cry, a loud, dry, keening sound like an animal left alone too long. I pulled his head to my shoulder and rocked him, my cheek against his hair. There are times when loss will bind you tighter than happiness or humor or music ever can.

College, Jimmy T. said, was just a place where all the problems of the world masqueraded as department names, but I might as well go anyway. "Someone's got to help me undo all the damage that's been done, and they'll take us more seriously if you have a college degree," he explained. Before I'd even met Jimmy T. I'd been accepted at a school in Illinois, and throughout the summer my departure date hung over us like a heavy Great Plains sky. As August merged into September, Jimmy T. still wasn't sure what he'd do in the fall. Maybe take some courses at the community college in town: philosophy, or religion, or poetry or film. He once casually mentioned coming to Chicago with me. My evasive "Yeah ..." surprised us both, and told him not to offer again. We both knew he was only grasping for a plan as he watched his previously reliable audience begin to disperse, moving on to college, the military, and jobs in other states.

This hadn't been the promise. The promise had been that we'd stay young together, follow our dreams, and one day land on the cover of Newsweek or Rolling Stone. It hadn't accounted for the powerful force that smoothly propels upper-middle-class kids out of high school and into whatever it is they're expected to do next.

We'd counted on Springsteen, at least, to keep his original vow, but even he couldn't sustain it forever. With the release of Nebraska in the fall of 1982, he made the sudden transition from the prophet of one generation's rhapsody to the chronicler of another's demise. The album was a veritable avalanche of fractured dreams, filled with stories of plant shutdowns, home foreclosures, and debtors driven to desperate means.

Springsteen was just describing the times, I suppose, but they weren't my times anymore. The first time I listened to Nebraska and heard Everything dies, baby that's a fact, but maybe everything that dies someday comes back, was 
the first time I'd ever listened to a Bruce Springsteen song and thought, You are wrong. You are so completely wrong.

The night before I left for college, I tacked a calendar on Jimmy T.'s bedroom wall and counted off the days until I'd be home for Thanksgiving break. "Seventy-four," I told him with manufactured optimism as he sat sullenly on the edge of the bed, wrists dangling between his knees. "When you wake up in the morning, it'll be only seventy-three."

"I know how to subtract."

Overnight, I had become the traitor, he the betrayed. "Don't leave me," I pleaded, as I held onto him at the door.

"What?" he said. "You're the one who's getting on the plane without me."

Which I did, in the middle of September, on a direct flight to Chicago from New York. The first friend I made in my dorm became my closest one that year, a prep school graduate from Massachusetts with Mayflower ancestry and an album collection filled with Joni Mitchell, Johnathan Edwards, and Neil Young. "Bruce Springsteen?" she asked, scrunching up her nose in thought. And then, after a pause, "Isn't he that short guy from New Jersey?" By the second week of school, I'd buried all my cassette tapes in the bottom of a desk drawer. It's frighteningly easy to abandon the familiar when you discover it might be cliché.

Jimmy T. mailed me a letter in late September saying he couldn't contact me again until Halloween, because he was going on the road with his new band. So you can imagine my surprise when, in mid-October, I returned from an anthropology class on a Thursday afternoon and found him sitting alone in the first floor lounge of my dormitory, his black leather jacket with the chrome zippers at odd angles hopelessly out of place in the sea of Izod sweaters and wool peacoats from Peck \& Peck. He looked like a page from one short story ripped out and used as the bookmark in another, and when I first saw him I pulled my books into my chest and took a step back. He understood that step, he told me later. Hey! he said. Jimmy T. is no fool.

I didn't know exactly what pushed-or pulled-me back into the protective pocket of the glassed-in entryway. All I knew was in that moment after I instinctively withdrew, I suddenly understood something about relationships, something important. I understood there was a third kind of man my mother never told me about, the kind who you need, regardless of how 
he feels about you. The kind who offers you shelter when no one else even knows how to open a damn umbrella. The kind you can love but can never stay with for long, because the reason you ran to him in the first place was to gather the strength you needed to leave.

Jimmy T. stayed with me in Chicago for three days. We argued the whole time. We apologized in harmony, and then we argued some more. He wanted me to come back with him. I wanted him to leave alone. He wrote prose poems and taped them to my mirror when I was in class. The Chicago wind blows back your hair, you're living your art, your part. Long camel hair and scarf. We couldn't get past metaphor. "My axe has broken strings," he told me late one night, and I asked him to please for God's sake just drop the poetry and get to the point.

Our conversation, at the end: He said I came here to ask you to do something with me, and I said What? and he said But now I see you won't, and I said What? and he said I can't tell you, exactly, but it has to do with a quest I can't fulfill alone, and I said Please. Please would you just tell me what you mean. And he said All right, but you can't tell anyone, you swear? So I swore, and he nodded, and then he told me, very simply, that he was the Second Coming of Christ.

After he'd gotten back on the plane alone, after I'd called his mother from the pay phone at O'Hare, after the iceberg in my stomach finally began to thaw, I spent long nights wondering about the role I'd played in all this. Could I have prevented it somehow? Could I have been the cause? As the letters addressed to Jimmy T. came back marked "Return to Sender" in an angry scrawl, I lay on my bed and stared at the ceiling, looking for the words that would help me understand.

I was lying like this in my dorm room one night with the clock radio tuned in to Chicago's WXRT when I heard the first few bars of Jimmy T.'s song, the one he and his friend George had sold to the record company, come through on the air. I lay very still, barely breathing, trying to identify whose voice was singing the familiar words. I didn't dare move, too afraid I'd miss the end of the song and the name of the band.

I had to wait through two more songs before the deejay returned "... and before that we heard the Greg Kihn Band," he said, as the music faded away. "Doing a remake of an old Bruce Springsteen tune." 
Somewhere in the distance, I imagine, an engine revved and purred. Somewhere far beyond my reach, another boy shifted into high gear and pressed the pedal to the floor, believing he could sail on and on into the night. 